\title{
IDENTIFIKASI RISIKO CHANGE ORDER PROYEK KONSTRUKSI JALAN
}

\author{
Mega Waty ${ }^{1}$, Hendrik Sulistio ${ }^{2}$ \\ ${ }^{1}$ Jurusan Teknik Sipil, Universitas Tarumanagara Jakarta \\ Email :mega@ft.untar.ac.id \\ 2Jurusan Teknik Sipil, Universitas Tarumanagara Jakarta \\ Email:hendriks@ft.untar.ac.id
}

Masuk: 31-12-2020, revisi: 05-04-2021, diterima untuk diterbitkan: 10-04-2021

\begin{abstract}
ABSTRAK
Change Order adalah perintah kerja tertulis dan sah yang mengubah lingkup kontrak semula, dengan kompensasi yang sudah disetujui oleh pemilik dan kontraktor. Perubahan dapat berupa penambahan atau pengurangan lingkup pekerjaan, perubahan material, atau perubahan jadwal. Change Order menyebabkan biaya item kontrak membengkak, kesalahan perencanaan dan kelalaian serta perubahan ruang lingkup yang dapat dikurangi dengan mempertajam hasil perencanaan.. Lingkup penelitian pada konstruksi jalan di Indonesia khususnya provinsi DKI Jakarta dan Banten. Penelitian bertujuan untuk mengetahui identifikasi change order proyek konstruksi jalan. Data didapat dari data riil proyek konstruksi jalan dari tahun 2013- 2018 pada 16 paket proyek konstruksi jalan berupa kontrak addendum proyek konstruksi jalan. Berdasarkan kontrak addendum maka ditentukan pekerjaan tambah, pekerjaan kurang, penambahan item baru dan penghilangan item pekerjaan. Identifikasi risiko change order dilihat dari tiga aspek yakni penambahan dan pengurangan item pekerjaan, penghilangan item dan penambahan item baru dan keinginan dari pihak owner sehingga meningkatkan biaya kontrak change order. Penelitian ini mendapatkan 732 perubahan item pekerjaan konstruksi. Identifikasi risiko didapat dari frekuensi perubahan diatas 35\% yang merupakan frekuensi menengah yang cenderung meningkatkan terjadinya change order. Hasil identifikasi risiko didapat pada 31 item pekerjaan konstruksi, yang tertinggi persentase pada pekerjaan Marka Jalan Termoplastik, diikuti 30 item pekerjaan konstruksi lainnya.
\end{abstract}

Kata Kunci: identifikasi risiko; change order; proyek konstruksi jalan

\begin{abstract}
A Change Order is a written and legal work order that changes the scope of the original contract, with compensation that has been agreed upon by the owner and the contractor. Changes can be in the form of adding or reducing the scope of work, changing materials, or changing schedules. Change Order causes the cost of contract items to swell, planning errors and negligence as well as changes in scope that can be reduced by sharpening planning results. The scope of research on road construction in Indonesia, especially in DKI Jakarta and Banten provinces. This study aims to determine the identification of change orders in road construction projects. Data obtained from real data on road construction projects from 2013-2018 on 16 road construction project packages in the form of road construction project addendum contracts. Based on the addendum contract, added work, less work, addition of new items and removal of work items are determined. The identification of change order risk is seen from three aspects, namely the addition and reduction of work items, the removal of items and the addition of new items and the wishes of the owner, thereby increasing the cost of the change order contract. This study found 732 changes in construction work items. Risk identification is obtained from the frequency of changes above 35\% which is an intermediate frequency that tends to increase the occurrence of change orders. The results of risk identification were obtained for 31 construction work items, the highest percentage was for Thermoplastic Road Marking work, followed by 30 other construction work items.
\end{abstract}

Keywords: risk identification; change orders; road construction projects

\section{PENDAHULUAN}

Change order adalah persetujuan tertulis untuk memodifikasi, menambah atau memberi alternatif pada pekerjaan yang telah diatur dalam dokumen kontrak antara pemilik dan 
kontraktor, dimana perubahan tersebut dapat dipertimbangkan untuk masuk dalam ruang lingkup proyek yang asli/ orisinil, dengan kata lain ini merupakan kontrak modifikasi yang disyaratkan (Fisk, 1988)

Perubahan dalam proyek konstruksi selalu terjadi dan tidak bisa dihindari, (A.A. Gde Agung Yana et al., 2015) Perubahan desain merupakan gangguan dari kinerja pada suatu proyek konstruksi, terutama waktu dan kinerja biaya, yang terbanyak adalah perubahan design.(A.A. Gde Agung Yana et al., 2015). Change Order menyebabkan biaya menyebabkan item kontrak membengkak, kesalahan perencanaan dan kelalaian serta perubahan ruang lingkup yang dapat dikurangi dengan mempertajam hasil akhir perencanaan.(Taylor et al.,2012). Berdasarkan penelitian Taylor et al.,2012 menyatakan bahwa analisis dan hasil dari penelitian di Kentucky yang mengidentifikasi risiko change order memiliki kecenderungan ( trend) berdasarkan item penawaran pekerjaan yakni kelalaian kontrak yang biasanya disebabkan karena adanya penghilangan item pekerjaan, biaya kontrak yang membengkak dalam hal ini terjadi penambahan dana kontrak, permintaan dari pihak owner yang menyebabkan terjadi perubahan keseluruhan pekerjaan dalam kontrak.

Definisi dari kelalaian kontrak adalah dikuranginya beberapa item pekerjaaan dari kontrak asal sehingga terjadi perubahan kontrak yang menyebabkan nilai kontrak berkurang.Identifikasi Risiko adalah proses awal dari model CRMS. Proses harus melibatkan sebuah investigasi ke dalam seluruh sumber potensial risiko proyek dan akibat potensial proyek. Identifikasi risiko didefinisikan sebagai: proses sistematik dan identifikasi yang terus menerus, mengkategorisasi dan menilai signifikansi awal dari risiko yang bergabung dengan suatu proyek konstruksi. (AlBahar dan Crandall, 1990).

Proses manajemen risiko secara umum didefinisikan sebagai proses berulang yang dimulai dengan identifikasi faktor risiko, diikuti oleh penilaian kualitatif dan / atau kuantitatif dari efek risiko pada proyek, dan terakhir, pengembangan strategi mitigasi risiko untuk menjaga agar tetap optimal. struktur pengembalian risiko di antara peserta proyek (Zhi 1995; Wang et al.2004; Han et al.,2008). Beberapa penulis (misalnya, Al-Bahar dan Crandall 1990; Ward 1999; Zoysa dan Russell 2003; Wang et al. 2004) telah menekankan pentingnya fase identifikasi manajemen risiko, karena fase berikutnya (penilaian, analisis, dan lain lain) dilakukan berdasarkan faktor risiko yang teridentifikasi. Penelitian sebelumnya menyatakan bahwa persentase rata rata pekerjaan yang mengalami change order terbesar proyek konstruksi jalan yang terjadi di Banten adalah : Pekerjaan Saluran berbentuk U tipe DS $1(19,64 \%)$ dan di Jakarta pada pekerjaan Campuran Aspal Panas (44, 72\%) pada penelitian Waty dan Sulistio, 2020. Mengacu kepada besarnya persentase change order proyek konstruksi jalan maka dilakukan identifikasi risiko change order terhadap 16 proyek konstruksi jalan di Provinsi DKI Jakarta dan Provinsi Banten. Perumusan masalah yakni apakah identifikasi risiko change order proyek konstruksi jalan?

\section{METODE PENELITIAN}

Pengumpulan data dengan mengambil data riil yang ada di lapangan dari sumber yang dipercaya berupa addendum kontrak change order dari dinas terkait yakni dinas PUPR. Data berupa hard copy dan soft copy didapat dari pengumpulan data tersebut. 
Data yang didapat merupakan data riil proyek konstruksi jalan dari tahun 2013-tahun 2018.

Addendum kontrak berisi data perubahan, data kontrak asli dan perubahan perubahan yang ada di dalamnya. Dari addendum kontrak didapat: data pekerjaan tambah, pekerjaan kurang, penambahan item baru, penghilangan item pekerjaan, alasan perubahan pekerjaan, tanggal perubahan pekerjaan, pihak pihak yang terkait di dalamnya.

Lokasi penelitian : Provinsi DKI Jakarta dan Provinsi Banten

Identifikasi risiko change order dengan memperhatikan item pekerjaan yang mengalami pekerjaan tambah, pekerjaan kurang, penghilangan item pekerjaan dan penambahan item baru, karena ke empat hal ini merupakan bagian dari alasan perubahan change order yang terbesar yakni kelalaian kontrak, pembengkakan kontrak, dan keinginan pemilik sehingga terjadi pembengkakan biaya kontrak change order ( Taylor et al., 2012).

Perhitungan identifikasi risiko dengan mengacu kepada frekuensi dalam penelitian Hanna et al, 2013 yaitu:

LORR (Likelihood of Risk Realization) yang selanjutnya disingkat LORR adalah risiko yang kemungkinan risiko akan terwujud selama berada dalam lingkaran proyek yang dikenal dengan sebutan frekuensi. Kemungkinan dari realisasi risiko ditandai dengan nilai dari nol hingga lima: ( Hanna et al., 2013)

$0=$ Tidak dapat diaplikasikan ke proyek (0\% kesempatan)

$1=$ Kesempatan sangat rendah $(<10 \%$ kesempatan $)$

$2=$ Kesempatan rendah (10\%-35\% kesempatan)

$3=$ Kesempatan menengah (35\%-65\% kesempatan)

a. $\quad 4=$ Kesempatan tinggi $(65 \%-90 \%$ kesempatan $)$

$5=$ Kesempatan sangat tinggi $(>90 \%$ kesempatan $)$

Dengan mengacu kepada literatur tersebut maka bila frekuensi di atas 35\% merupakan kesempatan menengah yang harus diperhatikan, sehingga identifikasi risiko yang memiliki frekuensi diatas $35 \%$ harus diperhatikan karena sudah merupakan kesempatan menengah yang cukup mendapat perhatian dalam risiko.

\section{Analisis Data}

Analisis data dilakukan dengan cara sebagai berikut:

a. Identifikasi risiko dilakukan dengan menggunakan data real change order antara lain jumlah item penambahan proyek, jumlah item pekerjaan kurang, jumlah item penghilangan item pekerjaan dan jumlah item pekerjaan tambah proyek change order.

b. Melakukan analisis terhadap perubahan pekerjaan masing masing diatas

c. Melakukan rekapitulasi gabungan Perubahan pekerjaan

d. Melakukan perhitungan frekuensi perubahan item pekerjaan konstruksi jalan

e. Frekuensi yang melebihi $35 \%$ dikategorikan dalam identifikasi risiko pekerjaan konstruksi jalan

\section{HASIL DAN PEMBAHASAN}

Data yang didapat adalah dapat dilihat pada Tabel 1 dimana seluruhnya ada 16 proyek konstruksi jalan yang berasal dari tahun anggaran 2013 hingga tahun 2018 dan pada Tabel 3.1 juga terdapat 7 proyek yang merupakan balance budget dan 9 proyek yang merupakan proyek penambahan dana. 
Tabel 1. Data Proyek Konstruksi Jalan

\begin{tabular}{llllll}
\hline No & Paket & Kontrak & Kontrak Add & Tahun & Keterangan \\
\hline 1 & Jalan 1 & 17.891 .881 .000 & 17.891 .881 .000 & 2018 & Balance budget \\
\hline 2 & Jalan 2 & $28.501 .187 .000,00$ & 30.841 .291 .000 & 2018 & Penambahan dana \\
\hline 3 & Jalan 3 & $11.790 .233 .000,00$ & 12.969 .256 .000 & 2018 & Penambahan dana \\
\hline 4 & Jalan 4 & 2.647 .761 .000 & $2,890.502 .000$ & 2018 & Penambahan dana \\
\hline 5 & Jalan 5 & 7.322 .434 .000 & 8.022 .434 .000 & 2018 & Penambahan dana \\
\hline 6 & Jalan 6 & 33.692 .994 .000 & 37.062 .203 .950 & 2015 & Penambahan dana \\
\hline 7 & Jalan 7 & 9.839 .252 .000 & 9.839 .250 .825 & 2014 & Balance budget \\
\hline 8 & Jalan 8 & 17.514 .000 .000 & 17.514 .000 .000 & 2013 & Balance budget \\
\hline 9 & Jalan 9 & 13.805 .000 .000 & 13.805 .000 .000 & 2013 & Balance budget \\
\hline 10 & Jalan 10 & 58.800 .101 .000 & 58.800 .101 .000 & 2017 & Penambahan dana \\
\hline 11 & Jalan 11 & 11.998 .507 .000 & 12.198 .491 .000 & 2016 & Penambahan dana \\
\hline 12 & Jalan 12 & 46.752 .381 .600 & 46.752 .381 .600 & 2016 & Balance budget \\
\hline 13 & Jalan 13 & 22.738 .100 .000 & 22.738 .100 .000 & 2013 & Balance budget \\
\hline 14 & Jalan 14 & 18.783 .884 .000 & 18.783 .884 .000 & 2013 & Balance budget \\
\hline 15 & Jalan 15 & 19.167 .792 .500 & 21.080 .743 .000 & 2015 & Penambahan dana \\
\hline 16 & Jalan 16 & 43.776 .120 .000 & 48.153 .733 .000 & 2014 & Penambahan dana \\
\hline Sumbranan & & &
\end{tabular}

(Sumber : Dinas PUPR)

\section{Identifikasi Risiko Change Order berdasarkan Data Kontrak Change Order}

Identifikasi Risiko merupakan hal awal yang dilakukan dalam manajemen risiko dalam melakukan identifikasi terhadap suatu risiko dalam hal ini risiko change order. Melihat bahwa data riil change order merupakan data yang berisi penambahan pekerjaan sehingga mengakibatkan penambahan dana sehingga kontrak berubah. Data riil change order berisi data pekerjaan yang dihilangkan yaitu penghilangan item pekerjaan dengan demikian mengakibatkan kelalaian kontrak. Ada pula pekerjaan tambah dimana pekerjaan yang sudah ada ditambahkan volumenya demikian juga dengan pekerjaan kurang, yaitu suatu item pekerjaan berkurang volume pekerjaannya berdasarkan keadaan lapangan.

Mengacu kepada penelitian Taylor et al, 2012 yang menyatakan bahwa identifikasi change order mengacu kepada tiga hal yakni kelalaian kontrak, penambahan kontrak dan keinginan owner yang mendorong untuk seluruh aspek pekerjaan dalam konstruksi sehingga mengalami kenaikan kontrak, sehingga terjadi penambahan item pekerjaan baru, maka penulis menggabungkan analisis yang merekapitulasi dalam pekerjaan tambah, pekerjaan kurang, penambahan item baru dan penghilangan item pekerjaan konstruksi dari 1 data proyek konstruksi jalan di provinsi DKI Jakarta dan Provinsi Banten.

\section{Analisis Perubahan Proyek Jalan}

Terdapat 16 proyek konstruksi jalan sehingga mendapatkan 16 analisis perubahan proyek konstruksi jalan seperti dua contoh yang penulis berikan yakni analisis perubahan proyek Jalan 10, dimana proyek jalan 10 menempati urutan terbanyak dalam perubahan item pekerjaan proyek konstruksi jalan. 


\section{Analisis Kontrak Proyek Jalan 10}

Pada addendum kontrak change order jalan nomor 10 didapat 60 pekerjaan tambah dan 61 pekerjaan kurang dan 3 penambahan item pekerjaan baru dan 3 penghilangan item pekerjaan yakni antara lain:

a. Galian untuk drainase dan saluran

b. Pasangan batu dengan mortarc

c. Gorong gorong pipa beton bertulang diameter dalam $20 \mathrm{~cm}$

d. Saluran berbentuk U Tipe DS 1

e. Saluran berbentuk U tipe DS 1 (30x30cm/HD \& Tutup Saluran)

f. Saluran berbentuk U tipe DS 3 A

g. Beton K 250 ( f'c 20) untuk struktur drainase beton minor

h. Beton K 250 ( f'c 20) untuk struktur drainase beton minor ( ist)

i. Baja Tulangan untuk struktur drainase beton minorj.

j Kuras saluran

k. Galian Biasa

1. Galian Perkerasan Beraspal dengan Cold Milling Machine

m. Galian perkerasan beraspal tanpa Cold Milling Machinenn.

n. Galian Perkerasan Berbutir

o. Galian Perkerasan Beton

p. Timbunan Biasa dari Sumber Galian

q. Penyiapan Badan Jalanr

r. Lapis Pondasi Agregat Kelas A

s. Lapis Pondasi Agregat Kelas B

Rekapitulasi total perubahan proyek menjadi 732 dalam 16 perubahan proyek seperti yang dapat dilihat pada Tabel 2 di bawah ini berupa pekerjaan tambah, pekerjaan kurang, penambahan item pekerjaan baru, dan penghilangan item pekerjaan.

Tabel 2. Total Perubahan Proyek konstruksi Jalan

\begin{tabular}{clc}
\hline NO & Nama Proyek & Jumlah Perubahan \\
\hline 1 & Proyek jalan 1 & 56 \\
\hline 2 & Proyek jalan 2 & 60 \\
\hline 3 & Proyek jalan 3 & 40 \\
\hline 4 & Proyek jalan 4 & 10 \\
\hline 5 & Proyek jalan 5 & 39 \\
\hline 6 & Proyek jalan 6 & 31 \\
\hline 7 & Proyek jalan 7 & 30 \\
\hline 8 & Proyek jalan 8 & 34 \\
\hline 9 & Proyek jalan 9 & 62 \\
\hline 10 & Proyek jalan 10 & 127 \\
\hline 11 & Proyek jalan 11 & 45 \\
\hline 12 & Proyek jalan 12 & 88 \\
\hline 13 & Proyek jalan 13 & 16 \\
\hline 14 & Proyek jalan 14 & 22 \\
\hline 15 & Proyek jalan 15 & 38 \\
\hline 16 & Proyek jalan 16 & 34 \\
\hline & Total perubahan & 732 \\
\hline
\end{tabular}


Dengan melihat jumlah perubahan yang begitu besar maka dilakukan penelitian lebih lanjut untuk mengidentifikasi risiko change order dalam 16 proyek tersebut. Perubahan pekerjaan yang terjadi pada masing masing perubahan pada masing masing proyek akan diidentifikasi sehingga hasil analisis dapat dijadikan identifikasi risiko change order pada berbagai pekerjaan pada sejumlah proyek sebagai berikut di bawah ini yakni seperti yang terlihat pada salah satu tabel di bawah ini yakni Tabel 3 yang merupakan salah satu dari 16 identifikasi risiko proyek konstruksi jalan, dimana identifikasi proyek jalan 8 ini merupakan salah satu dari yang paling sedikit terjadi perubahan pekerjaannya yakni hanya 34 item perubahan pekerjaan baik pekerjaan tambah, pekerjaan kurang, penghilangan item pekerjaan maupun penambahan item baru pekerjaan. Kadang kadang dalam 1 pekerjaan terjadi perubahan beberapa kali atau juga dalam 1 pekerjaan dimana lokasi berbeda karena proyek jalan kebanyakan bukan hanya terpusat pada satu titik lokasi saja sehingga perubahan pada 1 item bisa terjadi di beberapa bagian lokasi pekerjaan, apalagi kalau lokasinya agak jauh maka dinamakan pekerjaan galian tanah $\mathrm{A}$, atau pekerjaan galian tanah B, begitu seterusnya. Setelah melakukan identifikasi per item pekerjaan konstruksi per tiap tiap proyek maka dilakukan rekapitulasi terhadap keseluruhan dengan frekuensi yang berbeda beda, dari frekuensi 4 hingga 15 perubahan, maka di dapat frekuensi pada Tabel 3. sebagai berikut:

Tabel 3. Identifikasi Change Order Proyek Jalan 8

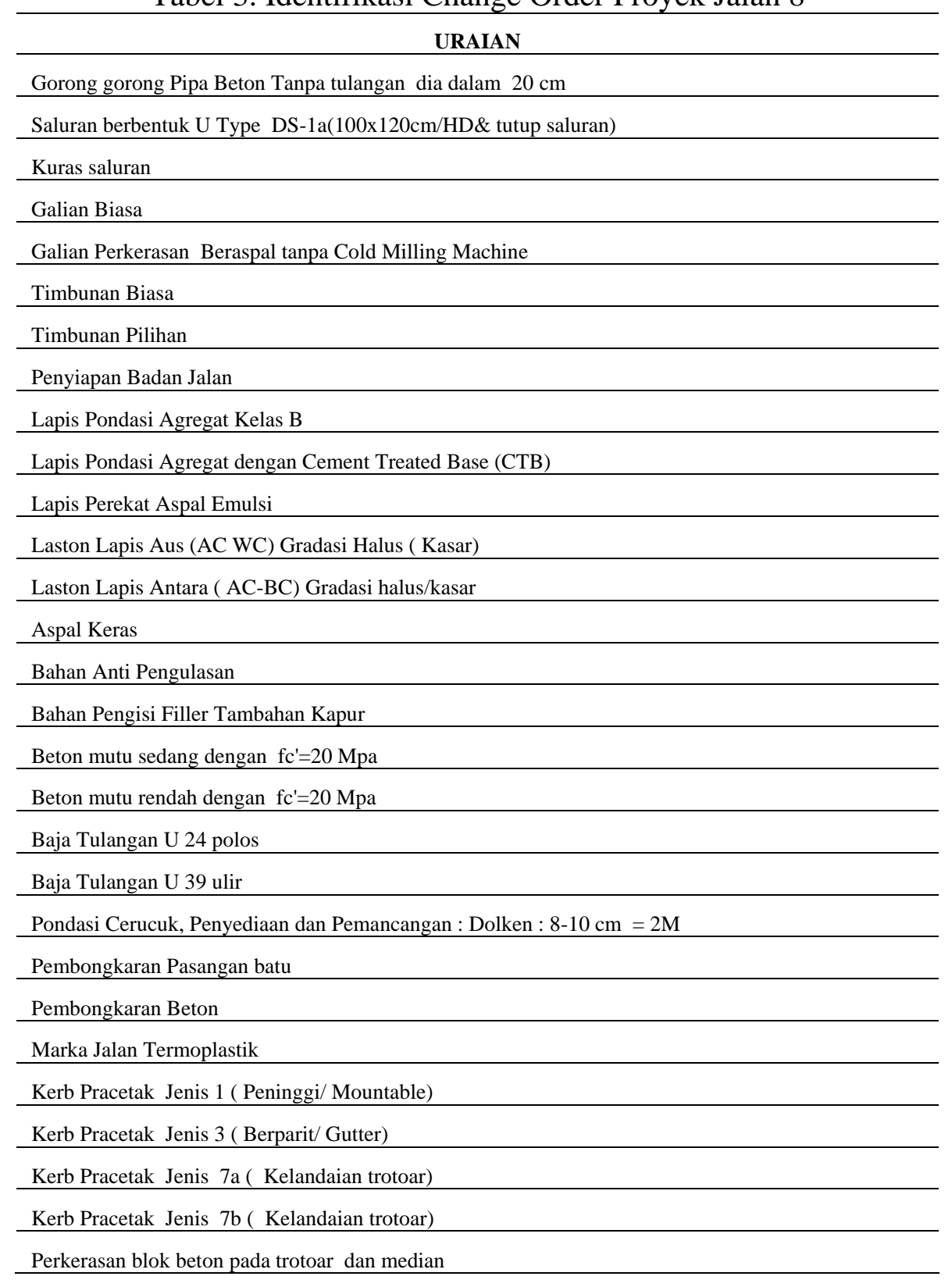


Tabel 4. Frekuensi Item Pekerjaan Konstruksi Jalan

\begin{tabular}{|c|c|}
\hline Frekuensi & Item Pekerjaan konstruksi Jalan \\
\hline 8 & Galian untuk Selokan Drainase dan Saluran Air \\
\hline 8 & Pasangan Batu dengan Mortar \\
\hline 9 & $\begin{array}{l}\text { Perkerasan Beton Semen untuk Pembukaan Lalu Lintas Umur Beton Lebih dari } 1 \text { hari dan } \\
\text { kurang dari } 3 \text { hari }\end{array}$ \\
\hline 8 & Galian Biasa \\
\hline 11 & Lapis Pondasi Agregat Kelas A \\
\hline 9 & Lapis Pondasi Agregat Kelas S \\
\hline 9 & Penyiapan Badan Jalan \\
\hline 15 & Marka Jalan Termoplastik \\
\hline 8 & Perkerasan Blok Beton pada Trotoar dan Median \\
\hline 10 & Bahan anti pengelupasan \\
\hline 10 & Lapis Perekat - Aspal Cair \\
\hline 10 & Pasangan Batu \\
\hline 9 & Lapis Pondasi Bawah Beton Kurus \\
\hline 11 & Laston Lapis Aus (AC-WC) \\
\hline 9 & Laston Lapis Antara (AC-BC) \\
\hline 12 & Beton mutu sedang fc'20 MPa \\
\hline 5 & Beton Mutu Rendah fc' $15 \mathrm{MPa}$ \\
\hline 11 & Beton Mutu Rendah fc' $10 \mathrm{MPa}$ \\
\hline 5 & Baja Tulangan U 32 Ulir \\
\hline 6 & Lapis Resap Pengikat - Aspal Cair \\
\hline 12 & Galian Perkerasan Beraspal tanpa Cold Milling Machine \\
\hline 11 & Baja Tulangan U 24 Polos \\
\hline 6 & Campuran Aspal Panas \\
\hline 9 & Timbunan Biasa \\
\hline 8 & Timbunan Pilihan \\
\hline 6 & Mandor \\
\hline 6 & Tukang kayu/tukang batu \\
\hline 6 & Pekerja \\
\hline 8 & Galian Perkerasan berbutir \\
\hline 4 & saluran berbentuk U type 2 \\
\hline 4 & saluran berbentuk $\mathrm{U}$ type 1 \\
\hline 9 & Kerb Pracetak Jenis 2 (Penghalang/Barrier) \\
\hline 9 & Kerb Pracetak Jenis 6 (Kerb dengan Bukaan) \\
\hline 9 & Kerb Pracetak Jenis 7a (Kerb pada Pelandaian Trotoar) \\
\hline 9 & Kerb Pracetak Jenis 7b (Kerb pada Pelandaian Trotoar) \\
\hline 9 & Kerb Pracetak Jenis 7c (Kerb pada Pelandaian Trotoar) \\
\hline
\end{tabular}

Frekuensi item pekerjaan konstruksi jalan yang bermacam macam dari 4 perubahan hingga 15 perubahan pekerjaaan konstruksi jalan seperti yang terlihat pada Tabel 4 , maka dicari pekerjaan yang mendapat porsi yang melebihi dari 35\% item pekerjaan konstruksi jalan dimana dari 16 proyek jalan pekerjaan ini memiliki frekuensi item pekerjaan yang melebihi dari $35 \%$. Kalau diandaikan dalam suatu pekerjaan jalan misalnya item pekerjaan galian biasa dimana pekerjaan 
ini terjadi perubahan pada lebih dari 6 proyek dari 16 proyek, berarti frekuensi lebih dari $35 \%$ karena $6 / 16 * 100=37,5 \%$. Bila mendapat frekuensi lebih dari $35 \%$ (Hanna et al., 2013) maka dijadikan identifikasi risiko change order secara keseluruhan, yang dapat dilihat pada Tabel 5 yang merupakan tabulasi identifikasi risiko change order proyek konstruksi jalan sebanyak 31 item pekerjaan jalan. Demikian pula sebaliknya bila mendapat frekuensi kurang dari $35 \%$ maka tidak dapat dijadikan identifikasi risiko change order proyek konstruksi jalan. Frekuensi tertinggi pada pekerjaan marka jalan termoplastik sebesar 93,75\% sehingga identifikasi risiko change order yang terbesar ditujukan kepada pekerjaan marka jalan termoplastik, begitu pula dengan item pekerjaan beton mutu sedang f'c $20 \mathrm{MPa}$ dan galian perkerasan tanpa Cold Macchine sebesar 75\% hingga kepada item pekerjaan Campuran aspal panas sebesar 37,5\% sebagai identifikasi risiko yang terkecil yang dapat dilihat pada Tabel 5.

Tabel 5. Identifikasi Risiko Change Order Proyek Konstruksi Jalan

\begin{tabular}{|c|c|c|c|}
\hline No & Jenis pekerjaan & Jumlah perubahan & Persentase \\
\hline 1 & Galian untuk drainase dan saluran air & 8 & $50 \%$ \\
\hline 2 & Pasangan batu dengan mortar & 8 & $50 \%$ \\
\hline 3 & $\begin{array}{l}\text { Perkerasan Beton Semen untuk pembukaan lalu lintas umur } \\
\text { Beton lebih dari } 1 \text { hari dan kurang dari } 3 \text { hari }\end{array}$ & 9 & $56 \%$ \\
\hline 4 & Galian biasa & 8 & $50 \%$ \\
\hline 5 & Lapis Pondasi Agregat Kelas A & 11 & $68 \%$ \\
\hline 6 & Lapis Pondasi Agregat Kelas S & 9 & $56 \%$ \\
\hline 7 & Penyiapan Badan Jalan & 9 & $56 \%$ \\
\hline 8 & Marka Jalan Termoplastik & 15 & $93,75 \%$ \\
\hline 9 & Perkerasan Blok Beton Pada Trotoar dan Median & 8 & $50 \%$ \\
\hline 10 & Bahan Anti Pengelupasan & 10 & $62,5 \%$ \\
\hline 11 & Lapis Perekat Aspal Cair & 10 & $62,5 \%$ \\
\hline 12 & Pasangan Batu & 10 & $62.5 \%$ \\
\hline 13 & Lapis Pondasi Bawah Beton Kurus & 9 & $56 \%$ \\
\hline 14 & Laston Lapis Aus ( AC-WC) & 11 & $68 \%$ \\
\hline 15 & Beton Mutu Sedang f'c $20 \mathrm{MPa}$ & 12 & $75 \%$ \\
\hline 16 & Beton Mutu Rendah f'c $10 \mathrm{Mpa}$ & 11 & $68 \%$ \\
\hline 17 & Galian Perkerasan Beraspal Tanpa Cold Milling Machine & 12 & $75 \%$ \\
\hline 18 & Baja Tulangan U 24 polos & 11 & $68 \%$ \\
\hline 19 & Timbunan Biasa & 9 & $56 \%$ \\
\hline 20 & Timbunan Pilihan & 8 & $50 \%$ \\
\hline 21 & Galian Perkerasan Berbutir & 8 & $50 \%$ \\
\hline 22 & Kerb Pracetak Jenis 2 & 9 & $56 \%$ \\
\hline 23 & Kerb Pracetak Jenis 6 & 9 & $56 \%$ \\
\hline 24 & Kerb Pracetak Jenis 7a & 9 & $56 \%$ \\
\hline 25 & Kerb Pracetak Jenis $7 \mathrm{~b}$ & 9 & $56 \%$ \\
\hline 26 & Kerb Pracetak Jenis 7c & 9 & $56 \%$ \\
\hline 27 & Mandor & 6 & $37,5 \%$ \\
\hline 28 & Pekerja & 6 & $37,5 \%$ \\
\hline 29 & Tukang kayu, tukang batu & 6 & $37.5 \%$ \\
\hline 30 & Campuran Aspal Panas & 6 & $37,5 \%$ \\
\hline 31 & Lapis Resap Perekat Aspal Cair & 6 & $37,5 \%$ \\
\hline
\end{tabular}




\section{KESIMPULAN DAN SARAN}

Setelah melakukan analisis maka didapat kesimpulan, yang mengacu kepada frekuensi perubahan yang tertinggi sebagai identifikasi risiko change order pekerjaan konstruksi jalan sebanyak 8 item pekerjaan konstruksi jalan adalah :

a.Marka Jalan Termoplastik

b. Beton Mutu Sedang f'c $>20 \mathrm{MPa}$

c. Galian Perkerasan Beraspal tanpa Cold Machine

d. Baja Tulangan U24 polos

e. Lapis Pondasi Agregat Kelas

f. Lapis Perekat Aspal Cair

g.Pasangan batu

h. Beton Mutu Rendah f'c $>10 \mathrm{MPa}$

Diikuti 23 item pekerjaan konstruksi lainnya.

Saran yang didapat dalam penelitian ini adalah lebih memperhatikan kepada 31 item pekerjaan konstruksi jalan sehingga risiko change order dan change order dapat dikurangi.

\section{Ucapan Terima Kasih}

Ucapan terima kasih ditujukan kepada Lembaga Penelitian dan Pengabdian Masyarakat Universitas Tarumanagara yang telah mendanai penelitian ini.

\section{REFERENSI}

Al-Bahar, J. F., \& Crandall, K. C. (1990). Systematic risk management approach for construction projects. Journal of construction engineering and management, 116(3), 533-546.

Fisk, E. R., \& Reynolds, W. D. (1988). Construction project administration. Wiley.

Han, S. H., \& Diekmann, J. (2004). Judgment-based cross-impact method for predicting cost variance for highly uncertain projects. Journal of Construction Research, 5(02), 171-192.

Han, S. H., Park, S. H., Kim, D. Y., Kim, H., \& Kang, Y. W. (2007). Causes of bad profit in overseas construction projects. Journal of construction engineering and management, 133(12), 932-943.

Hanna, A. S., Thomas, G., \& Swanson, J. R. (2013). Construction risk identification and allocation: Cooperative approach. Journal of Construction Engineering and Management, 139(9), 1098-1107.

Hsieh, T. Y., Lu, S. T., \& Wu, C. H. (2004). Statistical analysis of causes for change orders in metropolitan public works. International Journal of Project Management, 22(8), 679-686.

Taylor, T. R., Uddin, M., Goodrum, P. M., McCoy, A., \& Shan, Y. (2012). Change orders and lessons learned: Knowledge from statistical analyses of engineering change orders on 
Kentucky highway projects. Journal of Construction Engineering and Management, 138(12), 1360-1369.

Wang, S. Q., Dulaimi, M. F., \& Aguria, M. Y. (2004). Risk management framework for construction projects in developing countries. Construction management and economics, 22(3), 237-252.

Waty, M., \& Sulistio, H. (2020). PERHITUNGAN CHANGE ORDER PROYEK JALAN DI

BANTEN. Jurnal Muara Sains, Teknologi, Kedokteran dan Ilmu Kesehatan, 4(2), 211-220.

Yana, A. G. A., Rusdhi, H. A., \& Wibowo, M. A. (2015). Analysis of factors affecting design changes in construction project with Partial Least Square (PLS). Procedia Engineering, $125,40-45$.

Zhi, H. (1995). Risk management for overseas construction projects. International journal of project management, 13(4), 231-237.

Zoysa, S. D., \& Russell, A. D. (2003). Knowledge-based risk identification in infrastructure projects. Canadian Journal of Civil Engineering, 30(3), 511-522. 